Journal of Architectural Research and Education (JARE)

Vol. 1 (2) $99-106$

@I Wayan Runa, I Nyoman Warnata, Ni Putu Ratih Pradnyaswari Anasta Putri. 2019

\title{
Conservation of Cultural Heritage Architecture and Development of Tourism in Denpasar, Bali
}

\author{
I Wayan Runa ${ }^{1}$, I Nyoman Warnata ${ }^{2}$, and \\ Ni Putu Ratih Pradnyaswari Anasta Putri ${ }^{3}$ \\ 1,2,3 Department of Architecture, Faculty of Engineering and Planning, Universitas Warmadewa, \\ Denpasar - Bali, Indonesia \\ 1,2,3 Jalan Terompong No. 24 Tanjung Bungkak, Denpasar-Bali, Indonesia \\ Corresponding Author: sarwagunawayan@gmail.com \\ nyomanwarnata60@gmail.com \\ pradnyaswari.anasta@gmail.com
}

Received: 5 Oktober 2019
Article History:

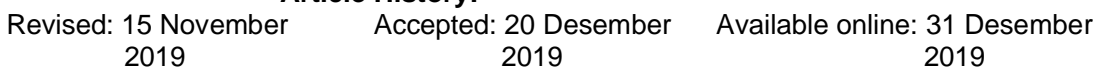

Abstract - This research aims to examine the role of conservation of cultural heritage architecture in the development of tourism in Denpasar and to describe the concept that shapes the downtown Denpasar (zone Z). Following the characteristics of the object of study (research questions), this research uses phenomenology as the paradigm. The qualitative method (phenomenology) is an inclusive and flexible method, which is always developing. This method helps to gain an understanding of meaning, develop theories, and describes complex realities. This research was conducted with the help of human instruments (the researchers), notebooks, voice recorders, and research assistants. Additionally, this research emphasizes qualitative techniques, in which researchers or human factors have an important role. Primary data consist of words and actions, while secondary data include documents, photos, and statistics. Results show that the cultural life of Denpasar citizen has a significant effect on the development of tourism in Denpasar, Bali. It is evident in the structure, functions, and meaning of downtown Denpasar Heritage City, especially in managing the area, planning, and building layout. The downtown Denpasar has a unique pattern called Pempatan Agung. In the context of tourism, the development of Denpasar should focus on creativity and culture. The responsibility of managing the area should be shouldered by the community, cultural experts, universities, NGOs, private companies, and the government. Also, there needs to be a continuous evaluation of the results of management.

Keyword: Pempatan Agung, culture, creativity.

\section{Introduction}

Cultural heritage is material cultural inheritance in the form of cultural heritage objects, cultural heritage buildings, cultural heritage structures, cultural heritage sites, and cultural heritage areas on land and/or in water that need preservation due to their values for history, science, education, religion, and/or culture through the stipulation process (Law No. 11 of 2011 concerning Cultural Heritage). UNESCO also has its definition of heritage, nature, and culture (UNESCO convention, 1972).

Mardika et al. (2010) revealed that Denpasar has potentials in the form of diverse archaeological and historical relics and urban settlement, both tangible and intangible. History, diversity, and local values that have been imbued with universal values (local genius) are ample reasons to call Denpasar one of Indonesian Heritage Cities.

Various narratives have examined the image of Denpasar (Peter J.M. Nas, 1996). Denpasar has many nicknames. For instances, City of Symbols due to the numerous symbols it had. City of Mountain because of the citizen's orientation that leads to Mount Agung with the humanist-ethnic 
dichotomy. City of Tradition, which refers to the abundance of local traditions in Denpasar such as Nyepi, Galungan, Tumpek rituals. City of Tourism due to a large number of domestic and foreign tourist arrivals. City of Arts, which is related to various types of art that grow in Denpasar such as percussion, dance, visual arts, and creative arts. The Slum City, which refers to a considerable number of slums on the banks of the river, in the market, and on the roadside. As Denpasar is home to heterogenous and pluralistic citizens, the city life also respects cultural diversity that manifests as multiculturalism tolerance (Geriya, 2011).

The variety of cultural heritage is valuable assets for Denpasar to achieve its aim to become a culture-oriented city in Bali and Indonesia. In culture-oriented cities, culture has three principal functions: as basic potential, as an approach, and as a holistic development orientation, especially in balance and sustainability.

As Bali's capital and the center of development, Denpasar is experiencing rapid growth and development. Although the local government tried to organize the city through the implementation of Land Consolidation, the development and growth of buildings are sporadic and not properly organized. It is because the prices of land in the arranged locations are not affordable by the citizens. Those problems will certainly pose a challenge to conservation efforts in Denpasar.

The rapid development of a developing area, especially in downtown Denpasar (zone Z) will result in the growth of disorganized alleyways. Roads in the downtown area are usually very congested as they double as a means of transportation and parking lot. Street line and building setback are often ignored by residents who live along the roads. The building façade keeps losing its Balinese identity as it is covered by billboards. Telajakan or the house front yard is crowded with street vendors, reducing the numbers of vegetation and inconveniencing the pedestrians. The citizens' awareness of cleanliness and order is still low. The city's utilities are in a mess, the sewers are not functioning, and the pavement is easily damaged. All of these conditions only bring discomfort to residents and tourists in the Heritage Area of Denpasar.

Denpasar City Regulation No. 6 of 2001 concerning Building Permits has set the requirements regarding the clear space between a building and a road and other objects by regulating the Building Coverage Ratio (BCR), Floor Area Ratio (FAR), and setback. Inventory and data collection of the width of the road, building setback, building façade organization, pedestrian ways planning, and all other related aspects are necessary to increase the discipline in carrying out development, especially in the Heritage Area of Denpasar that includes Jl. Thamrin, JI. Gadjah Mada, JI. Veteran, JI. Udayana, and Jl. Surapati. Therefore, the Government of Denpasar through the Spatial Planning and Housing Agency in the 2011 Fiscal Year allocated a budget to formulate a more detailed and comprehensive plan in the Heritage Area of Denpasar.

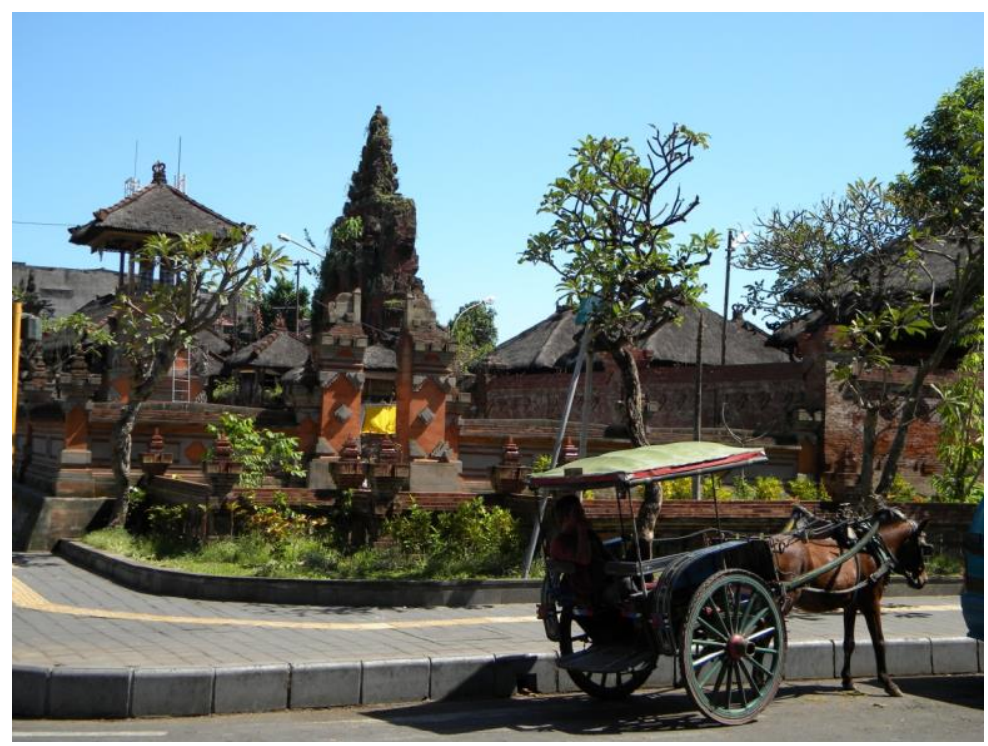

Figure 1: Pura Puseh and Pura Desa in Denpasar Adat Village on Jalan Gajah Mada as one of heritage city objects.

The concept of culture-oriented creative city has not been internalized and appreciated, as seen in the condition of the heritage city. People prefer to go to the mall rather than Zone Z. Without any preventive measures, people will abandon the heritage city. Other consequences include the 
disappearance of the love of heritage city, the decline in quality of heritage objects, the government's failure in driving valuable activities, and the emergence of new modern competitors.

\section{Methodology}

The object of this study is architectural heritage and tourism development in Denpasar, Bali. The focus of this study includes value systems, concepts, perceptions, diversity, uniqueness, local wisdom, and people's beliefs about things other than themselves. In line with the characteristics of the object of study, the paradigm used in this study is phenomenology. This study applies a qualitative method, which is inclusive and flexible and always evolving during the research. Meanwhile, this study aims to understand meanings, develop theories, and describe complex reality.

This study involves human instruments, notebooks, and voice recorders. Qualitative data for this study come from observations, individual documents, and in-depth unstructed interviews. A small number of samples are taken following a certain process. That process includes the selection of samples based on characteristics of a population and the aims of the study, sample analysis with inductive inference, and search for patterns, models, or themes. The relationship with respondents is familiar and equal and occurs within a long period. The study method emphasizes qualitative techniques, where researchers or human factors have an important role. Primary data for this study are words and actions, while secondary data are documents, photos, and statistics. Since this is qualitative research, data are collected from interviews, observations, and participant observations. Triangulation or cross verification of data from other sources is carried out to ensure the accuracy or validity of the research. Most of the research material consists of primary data, taken directly at the research site in Zone Z of Denpasar Heritage City.

\section{Results and Discussion}

\subsection{Conservation}

Conservation is an umbrella term for all conservation activities that adhere to international agreements contained in the 1981 Burra Charter. Conservation is the whole process of managing a place to preserve its cultural meaning. In other words, conservation means maintaining "something" for a long time so that its values can be passed on to the next generation. Conservation covers all maintenance activities required by circumstances. There are several ways to carry out conservation. For examples, by applying the continuity and change approach and economic insurance.

Hall (1966) states that there are three components of conservation that constitute the elements that shape the image of a region or building. These components are fixed, semi-fixed, and non-fixed components. The fixed component is the core of an area or building that cannot be changed (strict conservation). Meanwhile, the semi-fixed component includes ornaments, furniture, and so on that may or may not change (semi-strict conservation), depending on the building. Finally, the non-fixed component such as paint colors, space functions, materials, and so on can be changed (lenient conservation).

As a technique (form) of preservation, conservation is always changing, especially in conception. Today, preservation (conservation) includes environmental (natural) conservation and cultural conservation. Environmental conservation is a way to protect a specific area but still open to change. Meanwhile, concerning cultural conservation, Appleyard (1981) said that conservation efforts also include physical (artifacts) and social conservations. However, they do not have a significant difference in purpose. Lately, they are always carried out together. However, social conservation is emphasized to be the orientation of physical conservation.

Every place has unique socio-cultural elements. As such, research focuses on objective aspects of socio-cultural space only applies to the research location at the time of research. But, according to Lincoln and Guba in Meleong (1991), hypotheses of certain contexts of socio-cultural aspects are detachable and can be applied to other contexts even though incomplete. If researchers shift from one situation to another, their tasks are to describe and interpret the new, unique consequences that emerge. Natural generalization will follow and it is essentially a hypothesis rather than a conclusion.

In principle, development is aimed to preserve the nation's cultural values, increase human dignity, strengthen identity, and improve the quality of life. Therefore, the emphasis lies on the continuity of change so that cultural identity is maintained. Preservation of cultural identity or conservation of the "cultural" species of society is basically for the continuity of development and human welfare. It means development and conservation are supporting each other. In practice, there 
are many aspects that conservation must consider such as technical, regulatory, and institutional aspects.

The first step in physical (artifacts) conservation is an inventory of buildings that need conservation. According to Law No. 11 of 2010 concerning Cultural Heritage article 1 paragraph 1, cultural heritage is cultural inheritance in the form of objects, including cultural heritage objects, cultural heritage buildings, cultural heritage structures, cultural heritage sites, and cultural heritage areas on land and/or in water that need to be protected due to their values for history, science, education, religion, and/or culture through the process of stipulation.

Cultural heritage objects are natural or artificial objects. They include animate and inanimate objects and objects in one whole unit or parts or remnants that have a strong relation to culture and history of human development. Cultural heritage buildings mean built structures made of natural or artificial objects to meet the needs of spaces with or without walls and roof. Meanwhile, cultural heritage structures refer to built structures made of natural objects or artificial objects or both to meet the needs of activity spaces that are integrated with nature as well as facilities and infrastructure to accommodate human needs. Cultural heritage sites are locations on land or in water that contain cultural heritage objects, cultural heritage buildings, or cultural heritage structures resulted from human activities or exhibit evidence of past events. Finally, cultural heritage areas are a geographical spatial unit that has two or more cultural heritage sites that are located close to each other or show distinctive spatial characteristics.

As a consequence of conservation policies, all forms of physical changes to buildings becomes more restricted. Furthermore, maintenance of conserved buildings requires a considerable cost. For this reason, individuals or organizations that reap the benefits of tourism development should be taxed for the maintenance of the conserved buildings to ensure people's welfare, as stated in the development objectives.

\subsection{The Emergence of the City of Denpasar}

Denpasar was originally the core of the Kingdom of Badung. Then in 1958, Denpasar becomes the center of the government for the province of Bali, a position that Denpasar still holds until today. Being the center of the government of Bali, Denpasar is experiencing rapid growth in physical, economic, and socio-cultural contexts. The physic of Denpasar and its surroundings undergo significant advance. The lives of its people also show many characteristics of urban areas. Denpasar is not only the center of government but also the center of commerce, the center of education, the center of industry, and the center of tourism. Denpasar itself consists of four subdistricts, namely East Denpasar, South Denpasar, West Denpasar, and North Denpasar. The Central Government cannot be the only party that handles the rapid development in Denpasar as it occurs in various aspects of life. Therefore, it is time to form a city government that has the autonomy to regulate and manage urban areas so that the handling of urban problems becomes more effective and services to urban communities become faster.

Like other cities in Indonesia, Denpasar, as the provincial capital, is experiencing population growth and development. Furthermore, development in all sectors keeps increasing at a rapid pace. These circumstances have significant impacts on the city. In Denpasar, the capital of Bali, the average population growth is $4.05 \%$ per year. That number, coupled with the rapid growth rate of development in various sectors, strongly affect Denpasar. Despite being the youngest Level II Region in Bali, Denpasar has various urban problems that must be solved by the local government to meet the ever-increasing needs and demands of urban communities.

The origin of the city of Denpasar is related to the emergence of ancient kingdoms in South Bali. For instance, there was the Kingdom of Mengwi, which became the center of early development before the rise of the Kingdom of Badung. After the defeat of the Kingdom of Mengwi by the Kingdom of Badung, the center of development moved to the Kingdom of Badung that consists of three palaces: Puri Denpasar, Puri Pemecutan, and Puri Kesiman. The name of Puri Denpasar is then used as the name for the city of Denpasar. It is because Puri Denpasar is the largest among the three palaces before its fall into Dutch hands.

The development of Denpasar was not only supported by Puri Denpasar but also by the other two palaces. In Denpasar, the palaces have played an important role that they became the centers of commerce, socio-culture, and government. Additionally, the rise of Dutch colonialism also contributed to the growth of Denpasar as the center of government, education, and culture. In the colonial era, many changes took place, such as the shift in government structure from traditional government institutions to colonial government institutions. When the Dutch colonial government 
ended, the centers of development were preserved and then became the center of government in the era of independence.

Since becoming the capital of Bali, Denpasar faces many challenges. These challenges arise because of the increasing number of problems caused by the great migration in Bali and Denpasar as the center of the tourism industry in Central Indonesia. Now, the problem lies in the lack of careful planning regarding various problems that Denpasar will face in the future, such as the unclear concept of transportation, the increase of slums, and controlled spatial planning as the result of the increasing number of migrants (Ardhana I Ketut, 2004).

\subsection{The Architecture of Cultural Heritages in Denpasar}

Peter J.M. Nas in an article published in Jurnal Ilmu-IImu Sosial, Universitas Indonesia (1996) identified the image of Denpasar in various narratives based on the views of urbanology experts. Denpasar has many names, for instance, City of Symbols (due to various symbols Denpasar had). Other names include City of Mountain (it is related to the citizen's orientation to Mount Agung with the humanist-ethnic dichotomy); City of Traditions (refers to local traditions such as Nyepi, Galungan, and the Tumpek rituals); City of Tourism (refers to a large number of domestics and foreign tourist arrivals); City of Arts (due to various branches of art found in Denpasar, from percussion, dance, paintings, to creative arts); and the City of Slum (due to numerous slums on the banks of the rivers, around the markets, and on the roadside.

Denpasar is an indigenous city, in which its philosophies and concepts are heavily influenced by Balinese culture and Hinduism. As Denpasar becomes more heterogeneous and pluralistic, it also shows its respects towards cultural diversity, which takes form as tolerance based on multicultural insights. I Nyoman Mardika, I Made Mardika, and A.A. Rai Sita Laksmi (2010) revealed that Denpasar has urban settlements and archaeological and historical wealth, both the tangible and intangible ones, with potentials to be cultural heritage. The diversity, history, and local values (local genius) imbued with universal values are ample factors to call Denpasar one of the Heritage Cities in Indonesia.

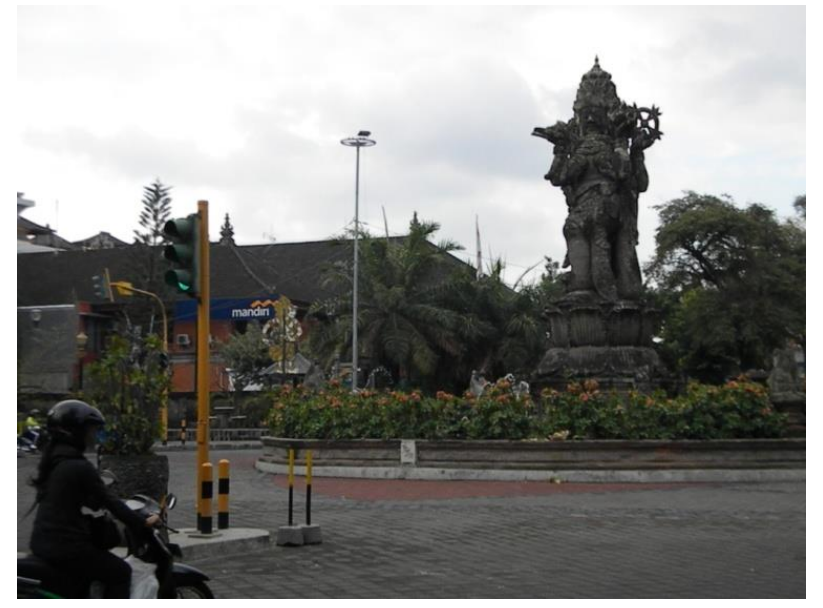

Figure 2: The Catur Muka Statue as one of the icons of Denpasar heritages.
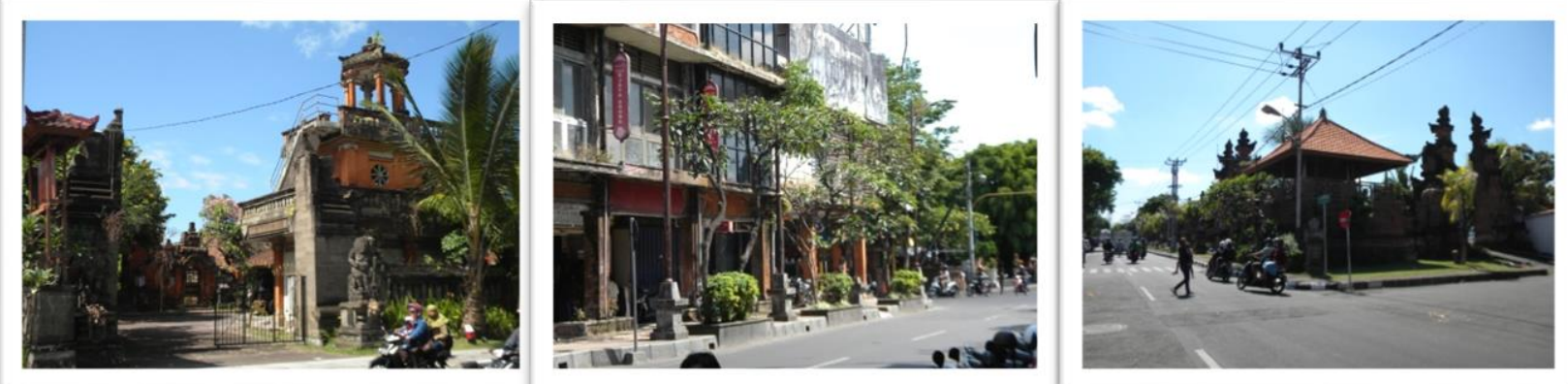

Figure 3: Various cultural heritages (left to right: a bale banjar, the façade of a shopping district, and a palace) are assets to make Denpasar a culture-oriented city in Bali and Indonesia.

I Wayan Runa, I Nyoman Warnata, Ni Putu Ratih Pradnyaswari Anasta Putri | 103 
Historical and cultural heritage, both the tangible and intangible ones, are an asset to make Denpasar a culture-oriented city in Bali and Indonesia. Culture (including various cultural heritages) in culture-oriented cities has three main roles: as basic potential, approach, and holistic development orientation in balance and continuity. Revitalization of historic areas is very important for various reasons: (a) site development (scale, urban space, and the relation between site and cities in creating aesthetics); (b) determination of the systems of circulation and network; (c) the appearance of the area and the building; and (d) the socio-economic aspects of the area.

\subsection{The Development of Tourism in Denpasar}

In terms of tourism, the development of Denpasar should refer to creativity and culture. As such, the development of 'abstract monuments' is intensified rather than the physical ones. 'Abstract monuments' refer to human resource, cultural heritage, and creativity channels. To propel the development of Denpasar, every citizen must become an 'abstract monument' or an excellent human being. To be an excellent human being means to be creative. Creativity itself is very dynamic.
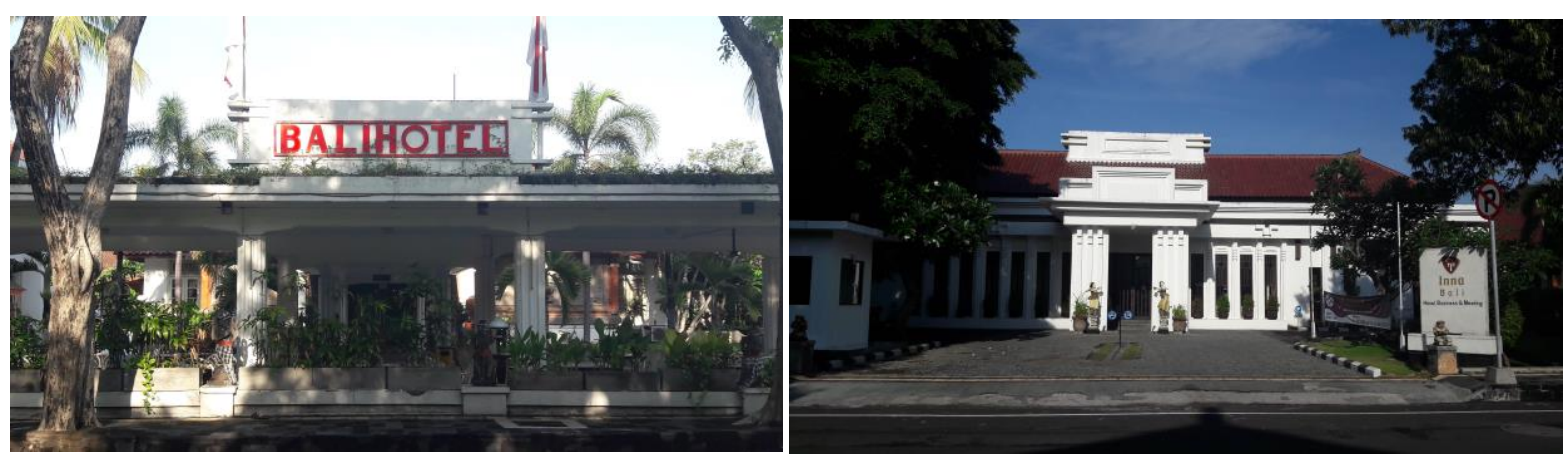

Figure 4: One of tourism facilities is a hotel in the center of Denpasar (Zone Z) with a Dutch colonial façade (left) and postmodern façade (right).

Therefore, people must be able to re-interpret, re-integrate, and adapt both to local culture and culture from other places but still be selective. The result of this process will be the identity of the urban community of Denpasar. The point is that people are expected to be creative, skilled, eager, and responsible. Creativity is multi-dimensional. In the western perspective, one dimension of creativity is economic creativity. Economic creativity has three important pillars: art and culture, technology, and entrepreneurship. It shows that there is a reciprocal relationship between economy, creativity, and arts and culture.

Technology is a driving factor in building a new mindset for the people of Denpasar. The advanced technology allows creative workers and unique cultural products to gain recognition from the world. However, there are at least four questions that Denpasar needs to answer: (1) how to encourage people to be creative workers and how to turn unique cultural potentials into tourism commodity through the process of selection; (2) how to brand the unique cultural potential of Denpasar as the icon of Bali; (3) how to develop thematic tourist destination groups with adequate infrastructure; and (4) how to manage tourism in Denpasar with professional management (Ardhana, 2014).

A 2009 study by anthropologist I Wayan Geriya et al. found that activities in a creative city need to maintain three principles of balance. The first principle is the balance between the cultural spirit that gives inspiration and the physical search that revolves around market and material; the second principle is the balance between the spirit of revitalization for conservation and the spirit of business-oriented entrepreneurship; and finally, the balance between integration philosophies that prioritize unity and multicultural insights that respect diversity.

The study also inventoried 66 unique cultures and 44 cultural potentials as the basis of a creative city. Among the 66 unique cultures, $33.3 \%$ are spiritual-cultural oriented, $16.7 \%$ are materialeconomy oriented, and $50.0 \%$ are double oriented (spiritual-cultural oriented as well as materialeconomy oriented). When linked to the 16 components of the creative economy set in Indonesia, it shows how 'rich' Denpasar is with its cultural uniqueness. This study indicated that Denpasar with the pattern of Pempatan Agung has potentials derived from the local culture. This study also revealed 104 | I Wayan Runa, I Nyoman Warnata, Ni Putu Ratih Pradnyaswari Anasta Putri 
that these potentials have considerable economic value. These potentials are unique only to Denpasar and will become Denpasar's identity and brand. Grouping of cultural potential types and distribution will form thematic tourist destination groups. These tourist destination groups are also potentials that encourage the movement of tourists in the city if managed professionally.

Denpasar tourism development policy (Anindya Putra, 2017) is based on unique culture. Aimed at the development of areas to become tourist destinations by utilizing their potentials in the form of groups, the policy covers (a) the theme of the area, unique products, routes and modes of choice, and quality standards and management; (b) quality standards of the destinations, products, services, human resources, and marketing; (c) form of organization, work mechanism, the scope of authority and responsibility, rights an obligations, and scope of services and fees; and (d) legal basis of the destinations, unique products, standardization of tourism quality, management, services, and fees.

Management of tourism follows a model that gives proportional roles to the community. The City Government (Department of Tourism) provides regulations and governance as well as thorough management and control, especially concerning quality, in the comfort of the area, promotions, and services. Meanwhile, the management is proportionally carried out by giving roles to third parties and local communities.

The concept of tourism in Denpasar is a city tour using a mode of transportation. The model of the travel is divided into two major frameworks: (a) a travel controlled by the Government (Department of Tourism) from the central point to each destination by a 4-wheeled vehicle with a maximum capacity of 10 people; and (b) within the area, the travel is adjusted to the theme and conditions in the area, where many choices of mode of transportation are available such as 4wheeled vehicles and bicycles. People can also travel by foot.

The first step in managing tourism is classifying the leading cultural potentials based on type domination and numbers within the area. That step also includes determining the type and nature of the region's potentials. The next step is establishing development programs and analyzing the potential of local organizations and regional management models. After that is analyzing the link and match between the regions and their unique potentials. Next is determining the Structure of Tourism Development in Denpasar by preparing program priority scale and tourism management models based on studies in each region. Finally, the last step is preparing Regional Regulations concerning Tourism Management in Denpasar.

The handling of tourism is the responsibility of all parties, including the community, cultural experts, universities, Non-Governmental Organizations (NGOs), private companies, and the government. Furthermore, management is required to preserve and improve the functions and benefits of the area. The establishment of a Historic Area Forum gives space for the government and stakeholders to formulate the policies and planning strategies concerning tourism. It is also necessary to supervise or control the work of government officials, law enforcement, local communities, the press, and NGOs. Finally, there needs to be a continuous evaluation of the results of the management.

\section{Conclusion}

The cultural life of the people of Denpasar strongly affects the development of tourism in Denpasar, Bali. It is evident in the structure, function, and meaning of the center of Denpasar Heritage City as shown by the following aspects: the management of the area, the planning, and the building layout. Steps taken in managing the area include an introduction to the physical condition of the city, which concerns the image of the city and its connotation, memories, experiences, hopes, and activity. The downtown Denpasar forms a pattern called Pempatan Agung, which is unique to Denpasar. Additionally, the revitalization of historic areas is very important for various considerations.

The blocks (streets) in the center of Denpasar have a neat grid plan with relatively limited open spaces and public facilities. The management of tourism in Denpasar starts with preparing the outline of the revitalization of areas related to the public interest. It is followed by the formulation of development programs. Meanwhile, anything related to private ownership are followed by regulations in the form of Regional Regulations. The implementation of the street line follows the regulations, while the planning of the outdoor space is done by planting vegetation that have been selected as the mascot of Denpasar and Bali to show the identity as well as by not using the road for parking. There is also an improvement of the pedestrian areas and road facilities to give comfort and safety for the pedestrians, including disabled people. 
Temples need to be conserved by applying the principles of traditional Balinese architecture, maintaining the radius of purity, and decorating the outdoor space with local vegetation that has been selected as the mascot of Denpasar. Office buildings that have adopted elements of Balinese architecture also need to be preserved. Additionally, the role of Museum Bali as a place to expand Balinese culture needs further assertion. Its outdoor space also needs proper management by adding rare local plants. Meanwhile, commerce and service buildings can have a maximum height of two floors at the front and a maximum of three floors at the back so that the cross-section will show a corridor that expands to the top. The building façade continues to experience changes towards modernization, reducing its uniqueness.

In terms of tourism, the most suitable direction for the development of Denpasar is towards creativity and culture. One of the dimensions of creativity is economic creativity, which stands on three pillars, namely arts and culture, technology, and entrepreneurship. In the future, Denpasar needs to respond to at least four issues in the following: (1) encouraging the community to be creative workers as well as transforming unique cultural potentials into tourism commodity through a process of selection; (2) branding the unique cultural potential of Denpasar as the icon of Bali; (3) developing thematic tourism destination groups with adequate infrastructure; and (4) managing tourism in Denpasar professionally.

\section{Acknowledgement}

Our gratitude goes to all the people in Denpasar for the information provided and the extraordinary team spirit that makes this research successful. We also would like to thank the Department of Public Works and Spatial Planning of Denpasar, Bali for the research project given for us.

\section{References}

Anindya Putra, I Gusti Putu, 2017, Model Pengelolaan Pariwisata Kota Denpasar, ISBN: 978-60273463-1-449 http: //pasca.unand.ac.id/id/prosiding-seminar-nasional-perencanaanpembangunan-inklusif-desa-kota, Regional and Urban Planning Study Program, Faculty of Engineering Universitas Hindu Indonesia - Denpasar, e-mail: igpanindya@gmail.com.

Anonim, 1981, The Burra Charter for the Concervation of Place of Cultural Significance.

Appleyard, 1979, The Concervation of European Cities.

Ardhana I Ketut, 2004, Denpasar: Perkembangan Dari Kota Kolonial Hingga Kota Wisata, The 1st international Conference on Urban History Indonesia in Universitas Airlangga, Surabaya on August 23-25, 2004.

Ardhana, I Ketut, 2014, Denpasar Smart Heritage City, Sinergi Budaya Lokal, Nasional, Universal, Published by Bappeda Kota Denpasar.

Geriya, I Wayan, 2011, Konsep Dasar, Dimensi Filosofi dan Strategi Konservasi Warisan Budaya Bali. A Paper in TOT and DOT of Balinese Cultural Heritage Conservation, Denpasar.

Geriya, I Wayan, et al., 2009, Kebudayaan Unggul: Inventori Unsur Unggulan Sebagai Basis Kota Denpasar Kreatif, Published by Bappeda Kota Denpasar.

Hall, 1966, The Hidden Dimension.

Mardika, Nyoman, Mardika, I Made, Rai Sita Laksmi, A.A., 2010, Pusaka Budaya. Representasi Ragam Pusaka dan Tantangan Konservasi di Kota Denpasar Bali (I Wayan Geriya, ed), Denpasar, Bappeda Kota Denpasar.

Moleong, L.J., 1991, Metodologi Penelitian Kualitatif, 3, 50, PT Remaja Rosdakarya, Bandung.

Patrialis Akbar, 2010, Law No. 11 of 2010 concerning Cultural Heritage, Indonesia's Minister of Law and Human Rights.

Peter J.M. Nas, 1996, Perlambangan di Denpasar tentang Pariwisata dan Tradisi in Jurnal IImu IImu Sosial, Jakarta, Universitas Indonesia, PT. Gramedia Pustaka Utama. 